\title{
YOGA SEBAGAI TERAPI ALTERNATIF TERHADAP PTSD PADA PENYINTAS COVID-19: TINJAUAN LITERATUR
}

\author{
Aurelia Suprestia Djuanto ${ }^{1}$, Jessica Aditya ${ }^{2}$, Kevin Laurentius ${ }^{3}$, Roswiyani Roswiyani ${ }^{4}$ \\ ${ }^{1}$ Program Studi Psikologi, Universitas Tarumanagara \\ Email: aurelia.705200240@stu.untar.ac.id \\ ${ }^{2}$ Program Studi Psikologi, Universitas Tarumanagara \\ ${ }^{3}$ Program Studi Psikologi, Universitas Tarumanagara \\ ${ }^{4}$ Fakultas Psikologi, Universitas Tarumanagara \\ Email: roswiyani@fpsi.untar.ac.id
}

Masuk : 09-07-2021, revisi: 02-09-2021, diterima untuk diterbitkan : 21-10-2021

\begin{abstract}
Survivors of COVID-19 are vulnerable to trauma as a result of experiencing social isolation during treatment, with fear and loneliness that can have long-term impacts on mental health. In this review, some related literature will be identified and evaluated, using a qualitative-based literature review to research yoga as an alternative treatment to reduce PTSD symptoms, alleviate, or even cure PTSD in COVID-19 survivors. Articles screening from several journals was carried out by tracing PubMed's journal publication database throughout the last five years and also categorizing two keywords as a reference for reviewing articles. The result of this literature review confirms that COVID-19 has a psychological effect on survivors, especially concerning PTSD when viewed from the largest indication. In addition, based on the results of ongoing research, yoga has shown a significant and promising impact in reducing PTSD symptoms. From this, it can be concluded that although there has been no research that directly examines the causality of the related review, yoga can be an alternative treatment to minimize symptoms and relieve PTSD in COVID-19 survivors. Based on the results of the review, there are many aspects that need to be investigated further, such as the influence of frequency and duration of yoga. More literature review and further research are essential for this topic, especially testing yoga programs as an intervention for COVID-19 survivors to determine its effectiveness and whether it can be implemented as a whole in the society, especially those who are COVID-19 survivors.
\end{abstract}

Keywords: Yoga, treatment, PTSD, COVID-19, literature review

\begin{abstract}
ABSTRAK
Penyintas COVID-19 tergolong rawan terhadap trauma akibat mengalami isolasi sosial selama perawatan, dengan rasa takut dan kesepian yang dapat memberikan dampak berjangka panjang pada kesehatan mental. Dalam tinjauan kali ini akan dilakukan identifikasi, serta pengevaluasian beberapa literatur terkait, menggunakan tinjauan literatur berbasis kualitatif untuk meneliti yoga sebagai terapi alternatif dalam menurunkan gejala PTSD, meringankan, atau bahkan menyembuhkan PTSD pada penyintas COVID-19. Penyaringan artikel dari beberapa jurnal dilakukan dengan menelusuri database publikasi jurnal PubMed dari lima tahun terakhir dan juga dilakukan kategorisasi dua kata kunci sebagai acuan peninjauan artikel. Hasil tinjauan pada literatur ini menegaskan bahwa COVID-19 memiliki dampak psikologis pada penyintas, terutama PTSD apabila dilihat dari indikasi terbesar. Selain itu, berdasarkan hasil penelitian yang telah berlangsung, yoga menunjukkan dampak yang signifikan dan menjanjikan dalam mengurangi gejala PTSD. Dari sini dapat disimpulkan bahwa walaupun belum ada penelitian yang secara langsung meneliti kausalitas dari peninjauan terkait, yoga dapat menjadi salah satu alternatif terapi untuk meminimalisir gejala dan meringankan PTSD pada penyintas COVID-19. Berdasarkan hasil peninjauan, banyak aspek yang perlu diteliti lebih lanjut seperti pengaruh dari frekuensi dan durasi yoga. Dibutuhkan lebih banyak peninjauan literatur dan penelitian lebih lanjut mengenai topik ini, terutama pengujian program yoga sebagai intervensi pada penyintas COVID-19, untuk mengetahui tingkat keefektifannya dan apakah dapat diimplementasikan secara utuh pada masyarakat, terutama yang merupakan penyintas COVID-19.
\end{abstract}

Kata Kunci: Yoga, treatment, PTSD, COVID-19, tinjauan literatur. 


\section{PENDAHULUAN}

\section{Latar Belakang}

Virus SARS-CoV-2, penyebab wabah COVID-19 telah menjadi pembahasan yang mendunia dan masih menuai perdebatan, terutama dalam bidang kesehatan. Berdasarkan data yang diambil oleh World Health Organization (WHO, 2021) per tanggal 13 Mei 2021, jumlah kasus yang tercatat di seluruh dunia sebanyak 160.074.267, dengan total kematian sebanyak 3.325.260 jiwa. Banyak pihak yang menekankan mengenai etiologi COVID-19 tanpa terlebih dahulu mempertimbangkan kausalitas jangka panjang yang mungkin terjadi dari hasil temuan saat ini (Vittori et al., 2020), dengan tujuan untuk meminimalisir kerugian yang masif baik secara materi, maupun dalam usaha mengurangi korban jiwa. Meskipun COVID-19 menjadi penyakit yang secara dominan menyerang aspek biologis seseorang, namun sebenarnya COVID-19 juga dapat berdampak terhadap kesehatan mental (Mazza et al., 2020).

Dengan adanya kebijakan pembatasan sosial dan pelaksanaan karantina selama pandemi, seluruh masyarakat menjalankan karantina dan isolasi diri demi mencegah virus menyebar lebih luas. Hal ini kemungkinan besar berlaku lebih ketat pada para pasien COVID-19. Menurut data dari PDSKJI (Perhimpunan Dokter Spesialis Kedokteran Jiwa Indonesia, 2020), dari 182 hasil swaperiksa, sebanyak $80 \%$ (46\% bergejala berat, 33\% sedang, 2\% ringan, dan sisanya tidak bergejala) mengalami gejala stres pasca trauma psikologis karena mengalami atau menyaksikan peristiwa tidak menyenangkan terkait COVID-19. Pengalaman ini berpotensi menjadi sumber trauma yang menakutkan bagi sebagian penyintas, serta dapat memicu stres akibat tekanan yang dialami selama masa karantina. Dampak dari PTSD sendiri dapat mengganggu kehidupan seseorang kedepannya, bahkan dampaknya bisa terasa dalam jangka waktu yang lama (Xiao et al., 2020). Studi yang dilakukan oleh Mazza et al., (2020) menginvestigasi penyintas COVID-19 dan hasilnya memperlihatkan morbiditas psikiatri berkisar antara 10\% hingga 35\% di tahap pasca sakit, dengan tingkat gangguan mental tinggi yang salah satunya merupakan PTSD.

Di tengah pandemi COVID-19, PTSD menjadi salah satu gangguan mental yang sangat rawan terjadi karena dipicu oleh perasaan kesepian, serta kekhawatiran yang muncul akibat pandemi (Liu et al., 2020). Hal ini terutama dirasakan oleh para penyintas yang mengalami dampak pandemi secara langsung. Apabila melihat dari pembahasan mengenai PTSD sendiri, sudah banyak literatur yang membahas baik mengenai PTSD, maupun cara untuk menangani PTSD mulai dari intervensi perilaku, pikiran, kegiatan fisik, dan sebagainya. Mengingat adanya keterbatasan dalam penanganan di masa pandemi, salah satu bentuk kegiatan fisik yang relatif mudah, aman, dan efektif untuk dilakukan adalah yoga. Yoga sendiri terbukti dapat meringankan gejala PTSD, yaitu melalui membaiknya gangguan tidur, pengurangan depresi, kelelahan, serta kecemasan (Cramer et al., 2017). Selain itu, walau olahraga pada umumnya meningkatkan gairah fisiologis, yoga telah terbukti sebagai kegiatan fisik yang dapat mengurangi hal tersebut pada pasien PTSD dan diyakini dapat memengaruhi patologi PTSD dengan meningkatkan regulasi somatik dan kesadaran tubuh, yang imperatif untuk regulasi emosi (van der Kolk et al., 2014 dalam Gallegos, 2017). Hal ini penting karena hyperarousal adalah salah satu gejala utama pada PTSD (NHS website, 2021). Maka melalui keterkaitan dan kausalitas tersebut, penulis menggunakan metode literature review guna mencari tahu lebih dalam mengenai topik yang diangkat melalui literatur terkait yoga sebagai intervensi pada PTSD dan hubungan antara PTSD dengan penyintas COVID-19. Dengan dilakukannya peninjauan ini, diharapkan dapat menghasilkan gagasan baru yang dapat menjadi pemicu untuk penelitian terkait kedepannya. 


\section{Rumusan Masalah}

(a) Apakah yoga dapat menjadi solusi alternatif untuk mencegah atau mengatasi PTSD pada penyintas COVID-19?; dan (b) Apakah terdapat penelitian yang membahas mengenai efek dari pemberian treatment berupa aktivitas fisik (yoga) kepada penyintas COVID-19 yang mengalami PTSD?

\section{METODE PENELITIAN}

Dalam proses peninjauan, penulis melakukan tiga tahap penyaringan dan mengkategorisasikan dua kata kunci yang berbeda untuk pencarian literatur, yaitu kata kunci A, "Yoga effect on PTSD" lalu kata kunci B "PTSD on COVID-19 Survivor". Kategorisasi ini dilakukan berdasarkan tujuan dari peninjauan literatur ini, yaitu untuk melihat keterkaitan dari dampak yoga sebagai terapi alternatif PTSD terhadap para penyintas COVID-19. Selain itu, penulis juga ingin memberikan usulan solusi alternatif guna memicu penelitian secara langsung berdasarkan hasil dari peninjauan.

\section{Kriteria Literatur}

Untuk meneliti hubungan antara yoga dengan penyintas COVID-19 yang mengalami PTSD, ada beberapa kriteria yang menurut penulis penting untuk dipertimbangkan, antara lain, (a) jenis literatur: Literatur yang membahas tentang hubungan antara yoga dengan PTSD untuk kategori pertama, lalu PTSD dengan penyintas COVID-19 untuk kategori selanjutnya. Penulis juga mencari literatur dalam kurun waktu lima tahun terakhir, literatur yang menggunakan Bahasa Indonesia atau Inggris, dan jurnal yang memiliki reputasi di atas kuartil 3 (Q3); dan (b) jenis metode: Literatur yang ditinjau menggunakan metode penelitian tertentu yang melibatkan kontak langsung dengan sumber utama, seperti menggunakan yoga sebagai salah satu bentuk intervensi utama; wawancara, yang dilakukan baik secara langsung maupun tidak langsung; serta survei yang dilakukan secara langsung, daring, atau menggunakan self-report questionnaires sebagai metode intervensi atau pengumpulan data dalam eksperimen.

\section{Pencarian dan Pengelolaan Data}

Penulis melakukan pencarian literatur dari database elektronik PubMed dengan strategi penyaringan yang dapat dilihat dalam Gambar 1. Tiga penulis meninjau judul, abstrak, dan menilai secara independen literatur yang berpotensi memenuhi kriteria. Proses identifikasi ini berlangsung selama pencarian literatur di tahap awal. Proses penyaringan dibagi menjadi tiga tahap yaitu (i) mengidentifikasi kriteria kata kunci, kurun waktu, dan bahasa; (ii) menyaring duplikat, judul dan abstrak yang tidak berkaitan dengan topik \& kualitas jurnal; (iii) lalu menyaring literatur dengan relevansi dan metode penelitian yang sesuai. Data literatur (penulis, judul, metode, intervensi, dan hasil) diekstrak dan diolah dalam Google Spreadsheet untuk meninjau kembali persamaan dan perbedaan dari masing-masing kriteria literatur. Penyaringan tahap akhir meliputi pembahasan secara bersama oleh penulis dengan cara berdiskusi mengenai rincian dan relevansi isi dari setiap literatur, serta menyoroti beberapa kalimat penting tertentu guna menyokong hasil dan pembahasan.

\section{HASIL DAN PEMBAHASAN}

\section{Hasil Pencarian Literatur}

Enam puluh tujuh artikel teridentifikasi dari pencarian database menggunakan kata kunci A, yaitu "Yoga effect on PTSD" dan delapan belas artikel teridentifikasi dari pencarian database menggunakan kata kunci B, yaitu "PTSD on COVID-19 Survivor". Dari kedua kata kunci yang telah ditelusuri, maka total artikel yang muncul dalam pencarian sebanyak 85 artikel. Setelah mengeluarkan 32 artikel yang berada di atas kurun waktu lima tahun (kata kunci $\mathrm{A}=16$ artikel; kata kunci B = 16 artikel), yang tersisa adalah 53 artikel. Satu artikel yang menggunakan non 
Bahasa Inggris (kata kunci $\mathrm{A}=1$ artikel; kata kunci $\mathrm{B}=0$ artikel) dikeluarkan dan tersisa 52 artikel. Jumlah tersebut adalah hasil dari penyaringan tahap pertama.

Pada tahap penyaringan kedua, 18 artikel yang merupakan duplikat atau memiliki judul yang tidak relevan (kata kunci $\mathrm{A}=6$ artikel; kata kunci $\mathrm{B}=12$ artikel) dikeluarkan. Karena berada pada reputasi artikel di bawah kuartil $2(\mathrm{Q} 2)$ (kata kunci $\mathrm{A}=2$ artikel; kata kunci $\mathrm{B}=0$ artikel), dua artikel dikeluarkan dan tersisa 34 artikel. Setelah menghapus 26 artikel yang tidak menggunakan jenis metode sesuai kriteria dan isi tidak relevan dengan topik pembahasan (kata kunci $\mathrm{A}=24$ artikel; kata kunci $\mathrm{B}=$ dua artikel), yang tersisa adalah enam artikel (tiga dari kata kunci $\mathrm{A}$, dan tiga dari kata kunci B).

\section{Gambar 1}

\section{Diagram Alur Penyaringan Artikel}

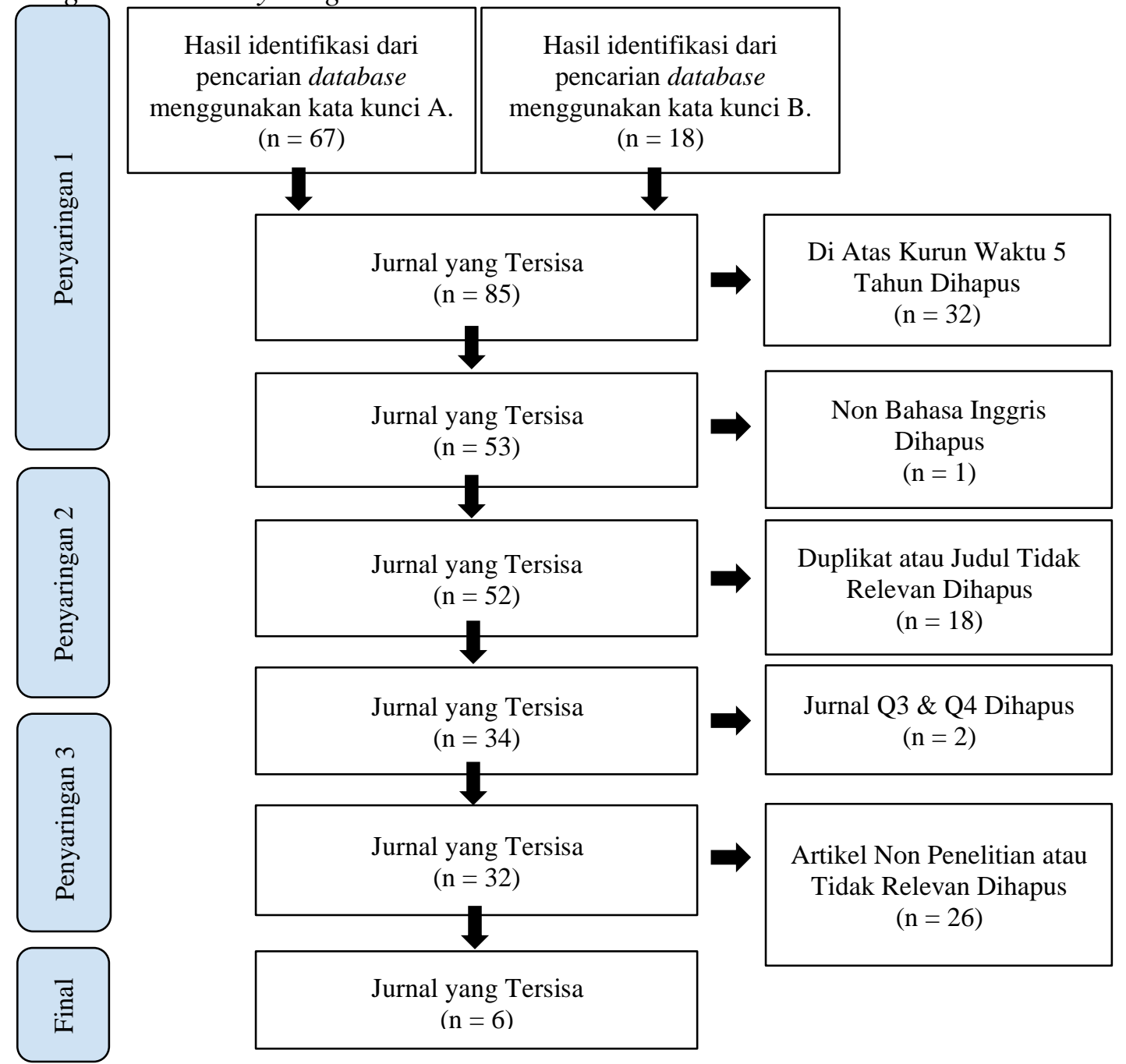




\section{Tabel 1}

Karakteristik Studi

\begin{tabular}{|c|c|c|c|c|c|c|}
\hline $\begin{array}{c}\text { Penulis, } \\
\text { tahun }\end{array}$ & Partisipan dan Latar & $N$ & $\begin{array}{c}\text { Mean } \\
\text { Usia }\end{array}$ & Metode & Hasil & Topik \\
\hline $\begin{array}{l}\text { Price, M., et } \\
\text { al. }\end{array}$ & $\begin{array}{l}\text { Wanita dengan PTSD } \\
\text { kronis. }\end{array}$ & 9 & 40.7 & $\begin{array}{l}\text { Intervensi berupa TCTSY } \\
\text { selama } 20 \text { minggu. }\end{array}$ & $\begin{array}{l}\text { Peserta mengalami penurunan } \\
\text { yang signifikan dalam PTSD. }\end{array}$ & \multirow{3}{*}{$\begin{array}{l}\text { PTSD - } \\
\text { Yoga }\end{array}$} \\
\hline $\begin{array}{l}\text { Davis, L., et } \\
\text { al. }\end{array}$ & $\begin{array}{l}\text { Usia } 18 \text { tahun atau } \\
\text { lebih yang sudah } \\
\text { terdiagnosis PTSD }\end{array}$ & 209 & 50.6 & $\begin{array}{l}\text { Membandingkan intervensi } \\
\text { HYP dengan WLP selama } 16 \\
\text { minggu. }\end{array}$ & $\begin{array}{l}\text { Gejala PTSD membaik secara } \\
\text { signifikan untuk kedua } \\
\text { kelompok, terutama HYP. }\end{array}$ & \\
\hline $\begin{array}{l}\text { Méndez, M., } \\
\text { et al. }\end{array}$ & Pasien PTSD dewasa & 12 & 44.2 & $\begin{array}{l}\text { Intervensi EMDR dan } \\
\text { trauma-informed yoga } \\
\text { (adaptasi dari trauma- } \\
\text { sensitive yoga dan program } \\
\text { yoga for the mind) selama } 5 \\
\text { hari. }\end{array}$ & $\begin{array}{l}\text { Gejala PTSD membaik secara } \\
\text { signifikan dengan ukuran efek } \\
\text { yang besar. }\end{array}$ & \\
\hline $\begin{array}{l}\text { Mazza, M., et } \\
\text { al. }\end{array}$ & $\begin{array}{l}\text { Pasien COVID-19 di } \\
\text { IRCCS Rumah Sakit } \\
\text { San Raffaele Milan. }\end{array}$ & 402 & 58 & $\begin{array}{l}\text { Wawancara klinis dan } \\
\text { kuesioner berupa self-report. }\end{array}$ & $\begin{array}{l}\text { Penyintas COVID-19 } \\
\text { menunjukkan prevalensi gejala } \\
\text { sisa psikiatri yang tinggi. }\end{array}$ & \multirow{3}{*}{$\begin{array}{l}\text { PTSD - } \\
\text { COVID1 } \\
\quad 9\end{array}$} \\
\hline Lahav, Y. & Orang Israel dewasa. & 976 & 44.37 & $\begin{array}{l}\text { Survei daring melalui } \\
\text { Qualtrics }\end{array}$ & $\begin{array}{l}\text { Sebagian besar peserta } \\
\text { melaporkan mengalami } \\
\text { setidaknya satu gejala kejiwaan } \\
\text { terkait COVID-19. }\end{array}$ & \\
\hline $\begin{array}{l}\text { Hamam, A., } \\
\text { et al. }\end{array}$ & $\begin{array}{l}\text { Orang Israel dewasa } \\
\text { penyintas trauma. }\end{array}$ & 528 & 42.61 & $\begin{array}{l}\text { Survei daring melalui } \\
\text { Qualtrics }\end{array}$ & $\begin{array}{l}\text { Lebih dari } 25 \% \text { sampel } \\
\text { memiliki setidaknya satu gejala } \\
\text { stres peritraumatik terkait } \\
\text { dengan pandemi. }\end{array}$ & \\
\hline
\end{tabular}

Note. Trauma Center Trauma-Sensitive Yoga (TCTSY), Holistic Yoga Program (HYP), Wellness Lifestyle Program (WLP), Eye Movement Desensitization and Reprocessing (EMDR).

\section{Karakteristik Studi}

Hasil penyaringan terakhir menunjukan enam literatur yang paling sesuai dengan kriteria dan jenis metode yang dicari. Tiga literatur dari kategori pertama (kata kunci A), menggunakan metode eksperimen dengan yoga sebagai salah satu intervensi utama pada program terapi yang dilakukan dalam penelitian tersebut. Partisipan dari ketiga artikel dari kategori pertama merupakan orangorang dewasa yang telah terdiagnosis dengan PTSD kronis sesuai kriteria untuk PTSD yang diukur menggunakan Clinician Administered PTSD Scale (CAPS). Dari ketiga artikel dalam kategori pertama, hanya penelitian oleh Price et al. (2017) yang mengambil partisipan 100\% wanita. Dalam kategori kedua (kata kunci B), satu literatur menggunakan metode wawancara klinis dan mengumpulkan hasil kuesioner dari partisipan, sedangkan dua literatur lainnya merupakan penelitian dengan metode dan populasi yang hampir sama, yaitu menggunakan metode survei secara daring dan mengambil sampel dari warga negara Israel dewasa. Rata-rata usia partisipan berkisar antara 42.61 sampai 44.37 tahun.

\section{PTSD dengan Yoga}

Price et al. (2017) mengambil sampel wanita $(M=40.7$ tahun) yang sudah terdiagnosis dengan PTSD kronis dan treatment-resistant, lalu diukur dengan Clinician Administered PTSD Scale (CAPS). Enam dari sembilan partisipan menyelesaikan seluruh treatment yang diberikan. Intervensi berupa Trauma Center Trauma-Sensitive Yoga (TCTSY), hasil modifikasi dari hatha yoga treatment, selama 20 minggu antara, sebelum, dan sesudah penilaian. Partisipan diharuskan untuk tetap menjalankan psikoterapi suportif, serta perawatan farmakologis yang sudah ada sebelumnya selama studi ini berlangsung. Kelas yoga dipimpin oleh instruktur dan dihadiri setiap minggu selama satu jam. Selain menghadiri kelas, partisipan juga direkomendasikan untuk berlatih 
menggunakan DVD atau CD TCTSY (Trauma Center Trauma-Sensitive Yoga) sebagai panduan di rumah selama 30 menit, 3 kali seminggu. Sampel secara keseluruhan membuktikan rata-rata skor antara pretreatment (satu minggu sebelum dimulai) dan follow-up setelah dua bulan turun $64 \%$ pada skor CAPS.

Davis et al. (2020) membandingkan dua program, yaitu Holistic Yoga Program (HYP) dan Wellness Lifestyle Program (WLP). Hasil menunjukkan bahwa gejala PTSD pada individu berusia 18 tahun atau lebih yang sudah terdiagnosis PTSD menggunakan CAPS-5 membaik secara signifikan untuk kedua kelompok menurut hasil skor CAPS-5 dan PCL-5 (PTSD Checklist for DSM-5), namun HYP menunjukan hasil penurunan yang lebih signifikan daripada WLP. Sampel terdiri dari 209 partisipan $(\mathrm{M}=50.6$ tahun) yang secara acak menghadiri salah satu dari dua intervensi mingguan tersebut selama 16 minggu. HYP terdiri dari instruksi yoga yang mengandung komponen hatha yoga, sedangkan WLP terdiri dari didaktik, diskusi, dan jalan kaki. HYP dibuat oleh terapis yoga untuk terutama mengatasi gejala hyperarousal PTSD. Saat orientasi, peserta HYP juga dibiasakan dengan dukungan praktik berupa DVD, perangkat audio, dan handout untuk di rumah. WLP dikembangkan oleh psikolog klinis yang sudah menyelesaikan pelatihan khusus dalam bidang psikologi kesehatan dan memiliki pengalaman trauma yang luas.

Laporan dari Méndez et al. (2018) menyatakan bahwa gejala PTSD membaik secara signifikan dengan ukuran efek besar menurut hasil skor PCL-5 pada pasien PTSD dewasa yang didiagnosis menggunakan kriteria CAPS-5. Partisipan terdiri dari 12 pasien rawat jalan (outpatient) $(\mathrm{M}=44.2$ tahun), 11 pasien menyelesaikan treatment. Intervensi berupa EMDR (Eye Movement Desensitization and Reprocessing) dan trauma-informed yoga yang diadaptasi dari traumasensitive yoga dan yoga for the mind selama lima hari. Pasien memiliki dua sesi EMDR berdurasi 90 menit setiap harinya. Sesi EMDR ditujukan untuk mengurangi tekanan emosional yang terkait dengan kenangan traumatis yang paling menjengkelkan. Di akhir hari-hari tersebut, pasien menerima satu jam program yoga. Di awal dan akhir hari, mereka memiliki pembicaraan suportif dengan perawat kesehatan mental selama 15 menit. Di antara sesi-sesi tersebut, pasien didorong untuk berolahraga dengan berjalan atau fitness.

\section{PTSD dengan Penyintas COVID-19}

Penyintas COVID-19 menunjukkan prevalensi dari sisa gejala psikiatri yang tinggi, dengan sampel $56 \%$ menunjukkan skor patologis untuk setidaknya satu gangguan seperti dilaporkan oleh Mazza et al. (2020). Sampel merupakan 402 pasien COVID-19 $(M=58$ tahun) dari tanggal 6 April sampai 9 Juni 2020. Studi kohort prospektif dilaksanakan di IRCCS Rumah Sakit San Raffaele di Milan, melalui wawancara klinis dan serangkaian kuesioner self-report yang digunakan untuk menyelidiki gangguan stres pasca-trauma (PTSD), depresi, kecemasan, insomnia, dan simtomatologi obsesif-kompulsif (OC). Penelitian melaporkan probabilitas PTSD, depresi berat, kecemasan, dan semua kondisi berbeban tinggi yang tidak menular lebih tinggi dari rata-rata pada penyintas.

Lahav (2020), meneliti 976 warga negara Israel dewasa $(M=44.37$ tahun) menggunakan sistem pengumpulan data berupa survei daring berbasis web (Qualtrics), yang dilakukan selama 18 hari dari tanggal 2-19 April 2020. Berdasarkan dari hasil penelitian, sebagian besar partisipan melaporkan mengalami setidaknya satu gejala kejiwaan (psychiatric symptom) terkait COVID-19. Selain itu, penyintas trauma, terutama Continuous Traumatic Stress (CTS) berisiko terkena tekanan psikologis kronis terkait COVID-19 karena memiliki gejala kecemasan, depresi, dan stres peritraumatik yang lebih tinggi dibandingkan dengan individu tanpa sejarah atau orang yang selamat dari peristiwa traumatis yang tidak berkelanjutan. 
Survei daring lain melalui Qualtrics dilaksanakan oleh Hamam et al. (2021) pada 528 warga negara Israel dewasa penyintas trauma $(\mathrm{M}=42.61$ tahun) untuk menilai gejala PTG (Post-Traumatic Growth), PTSD, dan stress peritraumatik yang terkait dengan pandemi. Hasil penelitian menunjukkan bahwa terdapat lebih dari seperempat sampel memiliki setidaknya satu gejala stres peri traumatik terkait dengan pandemi, dan $13.4 \%$ peserta memiliki skor total gejala stres peri traumatik yang menunjukkan bahwa gejala mereka signifikan secara klinis. Penelitian ini juga melaporkan bahwa faktor-faktor penguat stress peritraumatik, antara lain adalah dikarantina, berada pada kelompok berisiko tinggi, menjadi pengangguran atau cuti sejak merebaknya pandemi, dan lain-lain. Temuan ini memberikan dukungan lebih lanjut mengenai gagasan bahwa pandemi COVID-19 berpotensi menjadi pengalaman yang dapat memicu trauma.

\section{Pembahasan}

Berdasarkan hasil tinjauan pada enam literatur yang telah tersaring, tiga literatur dalam kata kunci A membahas yoga sebagai intervensi utama dengan tiga metode berbeda, dimana hal tersebut dapat menjadi sebuah pembahasan yang menarik untuk dibandingkan lebih lanjut. Program intervensi yang diterapkan oleh Price et al. (2017) menggunakan Trauma Center Trauma-Sensitive Yoga (TCTSY) yang dimodifikasi dari hatha yoga treatment. Selama 20 minggu, hasil menunjukkan bahwa perawatan dengan jangka panjang dan frekuensi yang lebih tinggi akan lebih menguntungkan bagi kesehatan mental dan fisik wanita yang menderita PTSD berat dan kronis. Dalam penelitian ini, yoga juga dikatakan menguntungkan apabila digunakan sebagai treatment tambahan, atau bahkan dapat menjadi resolusi utama untuk beberapa partisipan yang mengalami treatment-resistant. Partisipan mengalami tingkat pengurangan gejala serupa atau lebih tinggi menggunakan yoga dibandingkan dengan perawatan lain yang berfokus pada trauma (misalnya, EMDR, PE, terapi pemrosesan kognitif, dan lain-lain).

Salah satu perawatan lain yang berfokus pada trauma dibahas dalam penelitian oleh Méndez et al. (2018), yang menggabungkan trauma-informed yoga ke dalam program EMDR. Hal ini dilakukan karena trauma-informed yoga telah menunjukkan hasil yang menjanjikan sebagai intervensi yang berdiri sendiri, serta menunjukkan potensi yang dapat berkontribusi secara efektif pada perawatan multidisiplin untuk PTSD. Program perawatan intensif dari penelitian ini terbukti efektif untuk pasien yang sebelumnya tidak dapat memperoleh manfaat dari evidence-based treatment, terlihat dari respon pasien yang lebih baik pada program ini. Dilaporkan juga bahwa program dengan trauma focused therapy yang lebih banyak, dengan jeda waktu yang lebih lama antar sesi intervensi akan lebih efektif.

Berbeda dari dua penelitian tersebut, Davis et al. (2020) melakukan perbandingan antara dua program intervensi yang berbeda. Hasil dari penelitian ini menunjukan bahwa yoga dapat menjadi intervensi efektif untuk PTSD sebagai tambahan perawatan. Penelitian ini juga menemukan bahwa HYP menghasilkan peningkatan yang lebih signifikan secara statistik dibandingkan WLP pada hasil sekunder, terutama dalam body listening, depresi dan kecemasan, serta self-compassion. Peningkatan ini menunjukan bahwa yoga (HYP) lebih efektif untuk menanggulangi PTSD dibandingkan program yang mencakup aktivitas berjalan dalam intensitas rendah, yang dikombinasikan dengan metode pengajaran didaktik dan diskusi (WLP). 
Hasil literatur dari kata kunci A menunjukan ketiga penelitian memperlihatkan penurunan skor yang signifikan, walaupun ada perbedaan alat ukur antara dua penelitian yang memakai alat ukur CAPS dan satu penelitian dengan alat ukur PCL-5. Selain itu, ketiga program intervensi masingmasing menggunakan metode yoga seputar trauma-informed, trauma-sensitive, dan hatha yoga; dan menunjukkan bahwa yoga efektif sebagai perawatan tambahan secara umum atau bahkan perawatan utama untuk beberapa pasien PTSD yang treatment-resistant. Penelitian oleh Price et al. (2017) dan Davis et al. (2020) juga memberikan intervensi tambahan yang sama, yaitu partisipan diminta untuk melakukan yoga di rumah menggunakan DVD atau data audio. Sedangkan, Davis et al. (2020) dan Méndez et al. (2018) memberikan intervensi tambahan berupa konversasi bersama perawat terkait. Melihat dari kondisi para penyintas COVID-19, traumainformed yoga kemungkinan besar dapat digunakan sebagai pencegahan alternatif PTSD karena ditujukkan untuk mengembangkan rasa aman, dukungan, dan inklusivitas. Sedangkan traumasensitive yoga, terutama program TCTSY memiliki potensi sebagai intervensi klinis terhadap pasien PTSD, karena fokusnya untuk membuat pasien kembali terhubung dengan tubuh saat melakukan pose yoga (Livingston, 2021).

Salah satu penelitian membuktikan bahwa penyintas Severe Acute Respiratory Syndrome (SARS) dan Middle East Respiratory Syndrome (MERS) memiliki prevalensi yang lebih tinggi untuk terkena PTSD. Studi menunjukkan bahwa prevalensi semua jenis penyakit mental dalam 30 bulan setelah wabah SARS adalah 33,3\%, dan seperempat pasien mengalami PTSD (Ma et al., 2020). Seperti kedua epidemi tersebut, wabah COVID-19 kemungkinan besar juga berisiko memunculkan gejala psikopatologis serupa. Berdasarkan penelitian yang dilakukan oleh Mazza et al. (2020) didapatkan bahwa 56\% dari partisipan penyintas COVID-19 mengalami gangguan patologis, dimana dari populasi tersebut lebih dari seperempat populasinya mengalami gangguan PTSD dalam rentang waktu satu bulan setelah melalui perawatan di rumah sakit. Mazza et al. (2020) juga mengatakan bahwa COVID-19 dapat menyebabkan gejala sisa psikopatologis melalui infeksi virus langsung dari sistem saraf pusat (SSP) atau secara tidak langsung melalui respon imun (Wu et al., 2020, dalam Mazza et al., 2020). Penyebab lain juga dijelaskan oleh Lahav (2020), dengan memberikan argumen bahwa COVID-19 sendiri dan tindakan yang diambil untuk mengendalikan dampak dari virus ini kemungkinan besar memicu stres bagi banyak orang. Sedikit berbeda dengan kedua artikel lainnya, penelitian oleh Hamam et al. (2021) menyimpulkan bahwa COVID-19 dapat memicu munculnya gejala stres peri traumatik. Gangguan peri traumatik ini ditunjukkan sebagai salah satu prediktor terkuat untuk PTSD menurut sebuah meta analisis yang dilakukan oleh Nishi et al. (2012). Trauma-exposure dan gejala PTSD dikatakan juga dapat menguras sumber daya seseorang, kapasitas coping, dan dapat meningkatkan sensitivitas terhadap stres (Hobfoll, 2002, 2001; Resnick et al., 1995; Yehuda et al., 1995, dalam Hamam et al., 2021).

Berdasarkan pembahasan yang ditinjau menggunakan kata kunci B, penyintas COVID-19 berisiko mengalami sensitivitas terhadap lingkungan sekitar yang lebih tinggi, terutama apabila dampak dari virus ini telah dirasakan secara personal. Jika hal ini tidak ditanggulangi lebih lanjut mengingat adanya tingkat coping yang rendah pada penyintas yang memiliki gejala PTSD, maka terdapat indikasi lebih besar untuk mengalami gangguan yang lebih kronis. Selain itu dibutuhkan treatment yang paling mumpuni untuk dilakukan tanpa harus bersinggungan dengan lingkungan secara langsung. Berhubungan dengan kebutuhan ini, yoga dapat menjadi salah satu pilihan unggulan bila dilihat dari mobilitasnya yang cenderung fleksibel. Apabila dilihat dari pengaruh yang dipaparkan oleh artikel-artikel yang ditinjau, yoga secara garis besar berpotensi untuk meringankan gejala PTSD melalui banyak faktor, mulai dari biologis hingga psikis. 


\section{KESIMPULAN DAN SARAN Kesimpulan}

Dari hasil tinjauan yang sudah dilakukan, dapat disimpulkan bahwa yoga dapat menjadi salah satu solusi alternatif untuk mencegah atau mengatasi PTSD pada penyintas COVID-19. Walaupun belum bisa dikatakan sebagai solusi utama dari permasalahan saat ini, namun yoga dapat menjadi solusi tambahan atau pilihan alternatif yang dampaknya jelas berpengaruh secara signifikan dalam penurunan skor PTSD, yang juga didukung dengan pelaksanaannya yang relatif mudah dan aman. Hal ini selaras dengan penelitian-penelitian yang sudah pernah dilakukan sebelumnya, serta memberikan dorongan untuk dikaji lebih dalam lagi. Selain itu, yoga sendiri juga bermanfaat tidak hanya untuk pasien yang terindikasi PTSD, namun juga untuk menurunkan indikasi gejala atau mencegah terindikasi PTSD juga (Tibbitts et al., 2021), serta menjadi salah satu alternatif untuk pasien PTSD kronis dengan kondisi treatment-resistant. Selain itu, dapat disimpulkan juga bahwa kegiatan trauma-informed yoga yang telah dibahas kemungkinan besar dapat mencegah gangguan PTSD, sedangkan trauma-sensitive yoga berpotensi untuk mengatasi PTSD pada penyintas COVID-19. Penelitian secara langsung yang membahas mengenai efek dari pemberian treatment berupa yoga pada penyintas COVID-19 yang mengalami PTSD hingga saat ini masih sangat terbatas, sehingga tinjauan ini bisa menjadi landasan yang penting untuk menyokong penelitian berikutnya.

\section{Saran}

Saran bagi para penyintas COVID-19 yang terdiagnosis atau mengalami gejala PTSD adalah untuk mempertimbangkan penggunaan yoga sebagai treatment alternatif atau tambahan guna menurunkan gejala-gejala yang dialami. Mengingat minimnya sumber artikel yang melakukan penelitian secara langsung topik pembahasan, penelitian berikutnya disarankan untuk meneliti secara langsung mengenai pengaruh yoga tersebut, terutama pada individu dengan rentang usia yang lebih luas. Penelitian secara langsung disarankan berupa eksperimen dan intervensi menggunakan yoga pada penyintas COVID-19, sembari meneliti perbedaan efek dari yoga pada pasien PTSD dengan orang-orang yang sudah memiliki gejala, tetapi belum terdiagnosis terkena PTSD. Saran lain yang dapat dipertimbangkan, yaitu pengujian secara spesifik seperti pengaruh durasi, frekuensi, dan juga penelitian lebih lanjut terutama pada trauma-informed, traumasensitive, dan hatha yoga, tanpa menutup kemungkinan adanya jenis yoga lain yang terbukti efektif dalam penanggulangan PTSD.

\section{Ucapan Terima Kasih (Acknowledgement)}

Terima kasih yang sebesar-besarnya penulis sampaikan kepada Tuhan Yang Maha Esa, hanya karena rahmat-Nya, penulis dapat bertemu dan berkolaborasi dalam pembuatan karya ilmiah ini. Selanjutnya, penulis berterima kasih pada Universitas Tarumanagara selaku penyelenggara lomba SDG Awards yang menyediakan wadah untuk menuangkan isi pikiran penulis dan memberikan kesempatan untuk berkarya. Ucapan terima kasih juga penulis utarakan kepada para penulis dan peneliti dari sumber artikel jurnal yang digunakan dalam tinjauan literatur ini.

\section{REFERENSI}

Cramer, H., Lauche, R., Klose, P., Lange, S., Langhorst, J., \& Dobos, G. J. (2017). Yoga for improving health-related quality of life, mental health and cancer-related symptoms in women diagnosed with breast cancer. Cochrane Database of Systematic Reviews, 1. https://doi.org/10.1002/14651858.CD010802.pub2 
Davis, L., Schmid, A., Daggy, J., Yang, Z., O'Connor, C., Schalk, N., Do, A. N., Maric, D., Lazarick, D., \& Knock, H. (2020). Symptoms improve after a yoga program designed for PTSD in a randomized controlled trial with veterans and civilians. Psychological Trauma: Theory, Research, Practice, and Policy, 12(8), 904-912. https://doi.org/10.1037/tra0000564

Gallegos, A., Crean, H., Pigeon, W., \& Heffner, K. (2017). Meditation and yoga for posttraumatic stress disorder: A meta-analytic review of randomized controlled trials. Clinical Psychology Review, 58, 115-124. https://doi.org/10.1016/j.cpr.2017.10.004

Hamam, A., Milo, S., Mor, I., Shaked, E., Eliav, A., \& Lahav, Y. (2021). Peritraumatic reactions during the COVID-19 pandemic - The contribution of posttraumatic growth attributed to prior trauma. Journal of Psychiatric Research, 132, 23-31. https://doi.org/ 10.1016/j.jpsychires.2020.09.029

Lahav, Y. (2020). Psychological distress related to COVID-19 - The contribution of continuous traumatic stress. Journal of Affective Disorders, 277, 129-137. https://doi.org/10.1016/j.jad.2020.07.141

Livingston, M. (2021, 24 Mei). How trauma-informed yoga can help survivors heal. Shape.com. https://www.shape.com/fitness/workouts/yoga/trauma-informed-sensitive-yoga

Ma, K., Wang, X., Feng, S., Xia, X., Zhang, H., Rahaman, A., Dong, Z., Lu, Y., Li, X., Zhou, Z., Zhao, H., Wang, Y., Wang, S., \& Baloch, Z. (2020). From the perspective of traditional chinese medicine: Treatment of mental disorders in COVID-19 survivors. Biomedicine \& Pharmacotherapy, 132, 1-7. https:doi.org/10.1016/j.biopha.2020.110810

Mazza, M., De Lorenzo, R., Conte, C., Poletti, S., Vai, B., Bollettini, I., Melloni, E. M. T., Furlan, R., Ciceri, F., Roveri-Querini, P., \& Benedetti, F. (2020). Anxiety and depression in COVID-19 survivors: Role of inflammatory and clinical predictors. Brain, Behavior, and Immunity, 89, 594-600. https://doi.org/10.106/j.bbi.2020.07.037

Méndez, M. Z., Nijdam, M., ter Heide, F., van der Aa, N., \& Olff, M. (2018). A five-day inpatient EMDR treatment programme for PTSD: pilot study. European Journal of Psychotraumatology, 9(1), 1-10. https://doi.org/10.1080/20008198.2018.1425575

Nishi, D., Koido, Y., Nakaya, N., Sone, T., Noguchi, H., Hamazaki, K., Hamazaki, T., \& Matsuoka, Y. (2012). Peritraumatic distress, watching television, and posttraumatic stress symptoms among rescue workers after the great east japan earthquake. Plos One, 7(4), 16. https://doi.org/10.1371/journal.pone.0035248

NHS website. (2021, Mei 28). Symptoms-Post-traumatic stress disorder. NHS UK. https://www.nhs.uk/mental-health/conditions/post-traumatic-stress-disorderptsd/symptoms/

Perhimpunan Dokter Spesialis Kedokteran Jiwa Indonesia. (2020, April 23). Trauma psikologis terkait COVID-19. Perhimpunan Dokter Spesialis Kedokteran Jiwa Indonesia. http://pdskji.org/home

Price, M., Spinazzola, J., Musicaro, R., Turner, J., Suvak, M., Emerson, D., \& van der Kolk, B. (2017). Effectiveness of an extended yoga treatment for women with chronic posttraumatic stress disorder. The Journal of Alternative and Complementary Medicine, 10(10), 1-9. https://doi.org/10.1089/acm.2015.0266

Vittori, A., Lerman, J., Cascella, M., Gomez-Morad, A. D., Marchetti, G., Marinangeli, F., \& Picardo, S. G. (2020). COVID-19 pandemic acute respiratory distress syndrome survivors: Pain after the storm? Anesthesia \& Analgesia, 131(1), 117-119. https://doi.org/10.1213/ane.0000000000004914

World Health Organization. (2021, Mei 13). Coronavirus disease (COVID-19). World Health Organization. $\quad$ https://www.who.int/emergencies/diseases/novel-coronavirus-2 019? gclid=CjwKCAjwnPOEBhA0EiwA609ReRYYZKeuwpTu1- 


\section{dh5bNRdjCGeW7ud2Qq}

fO_F4f1vUmq5s4suSu8n0hoCsE4QAvD_BwE

Xiao, S., Luo, D., \& Xiao, Y. (2020). Survivors of COVID-19 are at high risk of posttraumatic stress disorder. Global Health Research and Policy, 5(1). https://doi.org/10.1186/s41256020-00155-2 